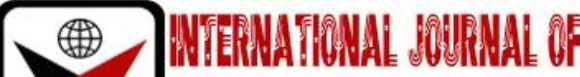

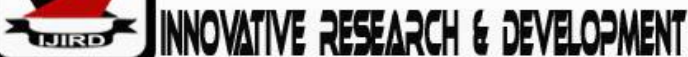

ISSN 2278 - 0211 (Online)

\section{Social Innovation and Skill Acquisition among University Graduates in Nigeria}

Dr. Binuyo, Adekunle O.
Associate Professor, Department of Business Administration and Marketing,
Babcock University, Ogun State, Nigeria
Dr. Adefulu, Adesoga D.
Associate Professor, Department of Business Administration and Marketing,
Babcock University, Ogun State, Nigeria
Asikhia, Olalekan U.
Professor, Department of Business Administration and Marketing,
Babcock University, Ogun State, Nigeria
Odumosu, Adefunke A.
Ph.D. Student, Department of Business Administration and Marketing,
Babcock University, Ogun State, Nigeria

\section{Abstract:}

Employers of labour and business organizations often complain that, graduates from Nigerian universities are illequipped and that there is a mismatch between the skills acquired by the graduates and employers' expectations. This mismatch could be due to lack of essential skills and competencies needed by the graduates to make them qualify and to compete with few existing jobs as well as contribute successfully to enterprise progress. However, social innovation has emerged as a potentially sustainable solution to economic, educational and societal challenges. Thus, this study focused on the effect of the social innovation dimension on skill acquisition among university graduates in Nigeria. A crosssectional survey design was adopted for the study. From the study population of 36,494, five hundred and thirty-three copies of a validated questionnaire with Cronbach's alpha reliability coefficient ranging from 0.750 to 0.937 were administered to 2019 Batch C Youth Corps Members deployed to six selected states which represented the six geopolitical zones in Nigeria. The data collected were analyzed using multiple linear regression. The results of the analyses revealed that social innovation dimensions had a positive and significant effect on skill acquisition among university graduates in Nigeria (Adj. $\left.R^{2}=0.254, F(4,510)=44.826, p<0.05\right)$. The findings further showed that education innovation $(\beta=0.257$, $t=4.2428, p=0.001)$ and digital innovation $(\beta=0.264, t=4.329, p=0.001)$ had a positive and significant effect on skill acquisition, entrepreneurship education had a positive but insignificant effect on skill acquisition $(\beta=0.056, t=1.012, p$ $=0.312$ ) and agricultural innovation had a negative and insignificant effect on skill acquisition among university graduates in Nigeria $(\beta=-0.039, t=-0.880, p=0.379)$. Hence, the study recommended that there should be curriculum reforms that will promote the use of social innovation for the development of essential skills to bridge the skill gap among Nigerian graduates.

Keywords: Agricultural innovation, digital innovation, educational innovation, entrepreneurship, entrepreneurship education, skill acquisition, social innovation

\section{Introduction}

Universities in Nigeria have been challenged by the situation of redesigning their curricula with a view to producing graduates with quality and essential skills that will make graduates creative, productive, dynamic, employable and potential entrepreneurs. The inability to acquire the necessary skills could make the graduates unfit in the labour market and incompetent to manage any business successfully. It has been observed that most universities in Nigeria are in the business of turning out graduates yearly, not minding the quality of skills acquired by the graduates (Akinyemi, Ofem \& Ikuenomore, 2012; Shivoro, Shalyefu \& Kadhila 2018). Consequently, poor skill acquisition on the part of the graduates is responsible for why most of them are incompetent and unable to contribute successfully to enterprise progress even though they are professionally or technically qualified (Edinyang, Odey \& Gimba, 2015), inability to become successful firm owners (Diyoke, 2014), incompetency in the use of digital tools to construct new knowledge and analyze digital resources (McGuinness \& Fulton, 2019), poor agribusiness development, low performance in agricultural sector (KayodeAdedeji \& Agwu, 2015), frustration, dejection, high level of dependence on family, friends and government (Ajufo, 2013), high poverty rate and increasing rate of unemployment (Afolabi, 2015). Be that as it may, it is becoming prominent that 
social innovation is a sustainable solution to youth unemployment, health crises, economic and other societal challenges (Kovacova, 2015). Some authors (Fayomi \& Fields, 2016; Odumosu, Binuyo, Adefulu, Asikhia, 2020; Onu, Eskay, Obiyo, Igbo \& Ezeanwu, 2012) have worked on the effect of social innovation on the development of education, critical thinking, graduate entrepreneurship and regeneration of education system. However, there have not been adequate studies on how social innovation affects skill acquisition among Nigerian graduates. Hence, this study intends to proffer solutions to this matter in question by investigating the effect of social innovation dimensions (educational innovation, entrepreneurship education, digital innovation and agricultural innovation) on skill acquisition among University graduates in Nigeria.

\section{Literature Review}

Social innovation is a new response to pressing social demands which affect the process of social interactions aimed at improving human wellbeing (Hubert, 2010). According to Bock (2012), social innovation is the new strategy and idea for promoting changes in terms of production, consumption and practices, guided by new attitudes and values which better meet the expectations and needs in the society through collaboration and partnership. Social innovation is about new ways, new ideas or re-shaping of old ideas to new ways to bring about improvement and positive change in the quality of life that impacts the society (Odumosu et al., 2020). This study emphasized educational innovation, entrepreneurship education, digital innovation and agricultural innovation as the dimensions of social innovation.

Educational innovation can be defined as the development of new concepts in the curriculum package while the obsolete ones are removed, due to the knowledge explosion in the society (Amadioha, 2016). It also means keeping students educated about new trends and technology in education. According to Mykhailyshyn, Kondur and Serman (2018), educational innovation refers to any purpose-oriented activity, organizational solutions, system, process or method of implementation of educational activities that significantly differ from the established practice and are first used in the institution which are aimed at improving the efficiency of functioning and the development of organization in a competitive environment. Educational innovation is essential for shaping the mindsets of young people and to provide the skills and knowledge that are central to developing an entrepreneurial culture. Similarly, Odumosu et al. (2020) defined educational innovation as the process of making changes to the way education is designed and delivered by adopting new and creative ideas to bring about effectiveness, efficiency and change to the educational sector. Entrepreneurship education is an aspect of education which develops the mindset of students to undertake the risk of venturing into something new by applying the knowledge and skills acquired in school (Ojo \& Abayomi, 2014). Egbefo and Abe (2015) also defined entrepreneurship education as a dynamic process of teaching students and potential entrepreneurs the essential skills required to build viable enterprises, equipping the trainees with skills needed for taking responsibility and developing initiatives of prospective trainees. Accordingly, entrepreneurship education can be defined as a form of education acquired by people that prepares them to be critical thinkers, accountable and innovators (Okolie, Elom, Ituma, Opara, Ukwa, Inyiagu \& Ndem, 2014).

Digital innovation deals with the innovation of products, processes, or business models using digital technology platforms across organisations (Ciriello, Richter \& Schwabe, 2018). This definition aligned with the definition by Irungu, Mbugua and Muia (2015) that defined digital innovation as any tool or technique, any product or process, any physical equipment or method of doing or making things that helps to improve human capability in an organisation. Similarly, Nambisan, Lyytinen, Majchrzak and Song (2017) defined digital innovation as the use of digital technology in a wide range of innovations for planning and coordinating of new products, new processes, new services, new platforms, or even new business models in a given context to produce the desired effect. These definitions are similar based on the concept that digital innovation deals with the use of digital tools in the form of products, processes, methods and equipment to improve existing products or knowledge. Agricultural innovation deals with the introduction of a new method, inputs, processes and organizational in order to increase competitiveness and to offer more cost-effective public goods in agriculture (Pisante, Stagnari \& Grant, 2012). Agricultural innovation can also be defined as a form of the package given to people especially farmers to improve agricultural productivity of their farm enterprises. The package can come in form of training on agribusiness, benefits given to farmers through the improvement of their soil fertility, conservation of soil nutrients, water and other natural resources, raising yields, improving pest management, decreasing effects of climate change and supporting other agricultural mechanisms (Ogundari \& Bolarinwa, 2018). In the same vein, Food and Agricultural Organisation of the United Nations (2018) defined agricultural innovation as the process whereby individuals or organizations bring new or existing products, processes or ways of organization into use for the first time in a specific context in order to increase effectiveness, competitiveness, resilience to shocks or environmental sustainability and thereby contribute to food security and nutrition, economic development or sustainable natural resource management. Skill is the ability to carry out or perform an activity competently (Skillscan 2012). Bhattacharyya and Mukherjee (2019) defined skill as the ability to discharge a task with effectiveness and efficiency to achieve determined goals. Bhattacharyya and Mukherjee further explained that developing skill in any job is the smartest way to work, knowledge without skill will make a graduate be less competitive in the labour market. Skills acquisition is the ability to learn and develop skills that are usually gained through training or experience (Ekong \& Ekong, 2016). It deals with the process of being trained on a task, job, duty or skill till the person becomes an expert (Udo, 2015). According to Longe (2017), skill acquisition is the knowledge given to a client to develop and strengthen the necessary skills to gain, maintain, and advance in a chosen area. Furthermore, Idoko (2014) defined skill acquisition as the possession of productive skills and creative ideas for the sake of creating employment for oneself and for others. Equally, Ezeh and Ekemezie (2015) defined skill acquisition as the abilities and competencies obtained through training by using the combination of cognitive and behaviour problemsolving approaches, both of which are used to strengthen a person's positive skill development. It can, therefore, be 
deduced that skill acquisition is the abilities and competencies derived from training to enhance effective work performance and gives the individual the capability to create employment for oneself and for others.

All graduates are expected to acquire skills as a part of their learning process in higher education. The skills that every graduate needs to be competitive and effective in the labour market include interpersonal skill, communication skill, critical thinking skill, personal development skill, self-management skill, self-control skill, presentation skill, leadership skill, numeracy skill and digital skill. Interpersonal skill is the ability to interact with people, participate effectively as members of a team, negotiate, inspire others to participate, satisfy customers, make decisions, manage time, work effectively and mitigate conflict with colleagues. Communication skill is the capability to effectively convey information verbally and in writing. Critical thinking skill is the ability to solve problems, effectively plan and organize creative thinking and devise new ways of doing things that will add value to the work environment. Personal development skill is the ability to have the right attitude towards work and to be open to learning and embrace change. Self-management skill deals with self-motivation, self-confidence. Self-control skill is used to manage personal feelings and how people react to challenges and problems both at work and in their private lives. Presentation skill is the ability to present information clearly and effectively in the workplace. Leadership skill deals with the ability to influence others towards the achievement of a goal. Numeracy skill deals with the ability to understand and use numerical data, statistics and graphs. Digital skill is the prowess to use IT devices both soft and hardware (Dhalum, 2017; Oresanya, Omodewu, Kolade \& Fashedemi, 2014; Sarkar, Overton, Thompson \& Rayner, 2016; Sodipo, 2014).

\subsection{Empirical Review}

Several scholars have examined the influence of dimensions of social innovation on skill acquisition but with a divergent point of view. For instance, Schroder and Kruger (2019) in their research work revealed a positive and significant effect of social innovation on skill acquisition. Their study pointed out that social innovation in education empowers students by enhancing their employability skills, which implies that, skill acquisition among students can be enhanced through social innovation. This aligned with the previous studies by Ismail and Mohammed (2014); Onyeike and Onyeagbako (2014) which revealed that social innovation is a new and modern way of repairing, modernizing and transforming the educational system. The finding of Pandey (2016) upheld that of Ismail and Mohammed (2014) and further specified that social innovation impact skill acquisition among students. In the same vein, studies by Aloysius, Ismail, Suandi and Arshad (2018); Dahunsi (2017) conducted in Nigeria indicated that social innovation dimension like educational innovation has a positive and significant interaction with skill acquisition among graduates. The studies asserted that training on soft skills enhances the school curriculum by addressing and designing essentials skills that will build up graduates' productivity at the workplace, boost their career development, and make them self-reliant after graduation. This result corroborated with the study by Sarkar et al. (2016) conducted in Australia, which further explained that the way to address the problem of skill mismatch among graduates is to devise methods of inculcating required skills and attributes into undergraduate students via the curricula review.

Equally, the study conducted by Akingbade and Aberuagba (2019) reported that a positive significant interaction exists between entrepreneurship education and skill acquisition. The study asserted that quality entrepreneurial education supports the development of business skill and support the modeling of self-reliant entrepreneurs. This finding upheld that of Yan, Yinghong, Lui, Whiteside and Tsey (2018) that declared that entrepreneurial training had a statistically significant positive impact on skill acquisition, applicable for future career and a range of other issues in daily life. This concurred with the study by Oresanya et al. (2014) which opined that practical entrepreneurship education enhances the skill acquisition among graduates for gainful employment in professional areas. Studies by Álvarez-Flores, Núñez-Gómez and Rodríguez (2017); Lyons, Zucchetti, Kass-Hanna and Cobo (2019) explored the interactions between digital innovation and skill acquisition and the findings displayed a positive relationship between digital innovation and skill acquisition. Their studies confirmed that undergraduate students lack the digital skills required for employment, the study also provided empirical evidence that digital skills have a strong influence on employment and wages. Likewise, the study by Green (2015) showed that the use of flipping classroom method provides a richer curriculum, helps students keep pace with digital and technological changes that revolutionize education.

Divergently, other studies have shown that social innovation has no significant impact on skill acquisition. The work of Orji (2013) on the assessment of employability skills development opportunities on students, found no significant relationship between educational innovation and skill acquisition, the study revealed that relevant employment skills are probably best learned in workplaces rather than in classroom settings. Consequently, Fayomi \& Fields (2016) reported that entrepreneurship education is not helpful in the development of skills. Alghamdi (2016) also found a negative association between digital innovation and skill acquisition. This study revealed that although digital innovation helps students to gain vast amounts of knowledge, yet it has a negative effect on their personal life and can cause serious physical and mental diseases such as obesity, computer vision syndrome, and depression.

\subsection{Theoretical Foundation}

\subsubsection{The Human Capital Theory (HCT)}

Human capital theory can be traced to the research of Theodore William Schultz (1902 - 1998) in 1961 and Gary Stanley Becker $(1930$ - 2014) who later developed the theory extensively in 1964. This theory was anchored on the assumption that formal education is a contributory factor to the development, efficiency and improvement of the productive capacity of an individual which result in higher pay. According to the proponents of the theory, investment in formal education is more advantageous than that of physical capital (Akhuemonkhan, Raimi \& Sofoluwe, 2013). 
Supporters of this theory include Alfred Marshall, Adam Smith, Robert Barro, among others who advocated that education plays a significant role in improving human capital, increases the productivity and earnings of individuals, boosts the level of productivity for the massive economic growth and development. Therefore, investment in education is the right investment because it is key to the economic growth of a country (Robert, 1991; Sofoluwe, Shokunbi, Raimi \& Ajewole, 2013).

Human capital theory and a good educational system are instrumental to the development of individuals and nations especially developing nations (Almendarez, 2011). Yet there are implications involved, especially in relation to the differences in government policies on education. The proponents of this theory advocated the need for policymakers to allocate significant resources in the expansion of educational systems (Akhuemonkhan et al., 2013). While some governments may be reluctant to invest in education, the positive returns from this investment will significantly outweigh the costs. Many of the developing nations have thus realized that the principal mechanism for developing human knowledge is the education system. Thus, they invest huge sums of money on education, not only as an attempt to impart knowledge and skills to individuals but also to impart values, ideas, attitudes and aspirations which may be in the nation's best developmental interest (Akhuemonkhan et al., 2013; Almendarez, 2011; Fitzsimons, 2015). Human capital theory is linked to social innovation in terms of the development of skills as an important factor in production activities. It is widely accepted that education improves the quality and level of production of graduates and helps to upgrade the general standard of living in a society (Darling-Hammond, 2017) and this could be enhanced through social innovation.

\section{Methodology}

A cross-sectional survey research design was adopted for the study. The population of this study comprised 25,578 National Youth Service Corps (NYSC) members deployed to serve in six selected states which represented the six geopolitical zones in Nigeria (Abuja, Bauchi, Kaduna, Enugu, Delta and Lagos state). The sample size was 533 derived from Krejcie and Morgan (1970) table. The study used a multistage sampling technique to select six states from the six geopolitical zones in Nigeria, while a snowball sampling technique was adopted to select the respondents among the youth corps members. A self-developed validated questionnaire with Cronbach's alpha reliability coefficient ranging from 0.750 to 0.937 was administered to the sample with a responds rate of $96.6 \%$. Multiple regression analysis was used to analyze the data.

\subsection{Model Specification}

$\mathrm{Y}=\mathrm{f}(\mathrm{X})$

$\mathrm{Y}=\mathrm{f}\left(\mathrm{x}_{1}, \mathrm{x}_{2}, \mathrm{x}_{3}, \mathrm{x}_{4}\right)$

$\mathrm{SA}=\beta 0+\beta_{1} \mathrm{X}_{1}+\beta_{2} \mathrm{X}_{2}+\beta_{3} \mathrm{X}_{3}+\beta_{4} \mathrm{X}_{4}+\mu \mathrm{i}$

$\mathrm{SA}=\beta_{0}+\beta_{1} \mathrm{EI}+\beta_{2} \mathrm{EE}+\beta_{3} \mathrm{DI}+\beta_{4} \mathrm{AI}+\mu_{\mathrm{i}}$

Where: $\mathrm{X}=$ Social Innovation, $\mathrm{Y}=$ Skill Acquisition (SA), $\mathrm{x}_{1}=$ Educational Innovation (EI), $\mathrm{x}_{2}=$ Entrepreneurship Education (EE), $x_{3}=$ Digital Innovation (DI), $x_{4}=$ Agricultural Innovation (AI), $\mu \mathrm{i}=$ error or stochastic term

\section{Data Analyses}

Analyses of data proceeded with diagnostic tests to ensure that the data did not violate important assumptions of regression analysis. These included tests for linearity, normality, homoscedasticity and multicollinearity. After the diagnostic tests, various analyses were carried out in line with the main objective of the study, which is to establish the effect of social innovation dimensions on skill acquisition among university graduates in Nigeria. Data were analyzed using multiple linear regression and the results are contained in Table 1.

\begin{tabular}{|c|c|c|c|c|c|c|c|c|c|}
\hline $\mathbf{N}$ & Variables & $B$ & $\beta$ & $T$ & Sig & $R^{2}$ & Adj. $R^{2}$ & $F(4,510)$ & F Sig ${ }^{2}$ \\
\hline \multirow[t]{5}{*}{515} & Constant & 18.653 & & 22.250 & 0.001 & \multirow{5}{*}{0.260} & \multirow{5}{*}{0.254} & \multirow{5}{*}{44.826} & \multirow{5}{*}{0.001} \\
\hline & $\begin{array}{l}\text { Educational } \\
\text { Innovation }\end{array}$ & 0.245 & 0.257 & 4.248 & 0.001 & & & & \\
\hline & $\begin{array}{l}\text { Entrepreneurs } \\
\text { hip Education }\end{array}$ & 0.039 & 0.056 & 1.012 & 0.312 & & & & \\
\hline & $\begin{array}{c}\text { Digital } \\
\text { Innovation }\end{array}$ & 0.174 & 0.264 & 4.329 & 0.001 & & & & \\
\hline & $\begin{array}{l}\text { Agricultural } \\
\text { Innovation }\end{array}$ & -0.025 & -0.039 & -0.880 & 0.379 & & & & \\
\hline
\end{tabular}

Table 1: Summary of Multiple Linear Regression Analysis for Effect of Skill Acquisition on Social Innovation Dimensions among University Graduates in Nigeria

a. Dependent Variable: Skill Acquisition

b. Predictors: (Constant), Agricultural Innovation, Education Innovation, Entrepreneurship Education, Digital Innovation Source: Field Survey (2020)

\subsection{Interpretation of Findings}

Table 1 presented the results of multiple linear regression analyses for the effect of the social innovation dimension (agricultural innovation, education innovation, entrepreneurship education, digital innovation) on skill acquisition among university graduates in Nigeria. The results revealed that social innovation dimensions have a positive and significant effect on skill acquisition among graduates $\left(A d j . R^{2}=0.254, F(4,510)=44.826, p<0.05\right)$. This means that 
the combination of social innovation dimensions was statistically significant in explaining changes in skill acquisition among graduates. The result of the table showed the $\mathrm{R}^{2}$ value 0.260 indicated that social innovation dimensions have a weak put positive relationship with skill acquisition among graduates in Nigeria. The analysis also showed that $A d j . R^{2}$ is 0.254 which implies social innovation dimensions (agricultural innovation, education innovation, entrepreneurship education, digital innovation) are responsible for about $25.4 \%$ of the changes that occur in skill acquisition among university graduates in Nigeria. The remaining unexplained $74.6 \%$ variance could be due to other factors that were not considered in this study model. The p-value of 0.001 implies that the regression model is significant at the 95\% significance level. The study further revealed that education innovation $(\beta=0.257, t=4.2428, p=0.001)$ and digital innovation $(\beta=0.264, t=4.329, p=0.001)$ have positive and significant effect on skill acquisition among graduates in Nigeria. However, entrepreneurship education has a positive but insignificant effect on skill acquisition $(\beta=0.056, t=$ $1.012, p=0.312$ ), and agricultural innovation has a negative and insignificant effect on skill acquisition among graduates in Nigeria $(\beta=-0.039, t=-0.880, p=0.379)$.

According to the regression equation model, when social innovation dimensions (agricultural innovation, education innovation, entrepreneurship education, digital innovation) are at a constant zero, skill acquisition among university graduates would be 18.653, implying that without social innovation dimensions, skill acquisition among graduates in Nigeria would be positive showing an improvement. The results of the multiple linear regression analysis indicated that when educational innovation and digital innovation are improved by one unit, skill acquisition will be positively affected with an increase of 0.245 and 0.174 respectively. The result suggests that educational innovation and digital innovation are important determinants of skill acquisition among graduates in Nigeria.

The multiple linear regression model to predict the effect of social innovation dimensions on skill acquisition among university graduates is thus expressed as:

$\mathrm{SA}=18.653+0.245 \mathrm{EI}+0.039 \mathrm{EE}+0.174 \mathrm{DI}-0.025 \mathrm{AI}$

Where:

SA = Skill Acquisition

$\mathrm{EI}=$ Educational Innovation

$\mathrm{EE}=$ Entrepreneurship Education

DI = Digital Innovation

$\mathrm{AI}=$ Agricultural Innovation

\subsection{Discussion}

The study set out to establish the effect of social innovation dimensions on skill acquisition among university graduates in Nigeria. The overall result of the multiple linear regression analysis showed that social innovation dimensions have a positive and significant effect on skill acquisition among graduates in Nigeria. The result implied that social innovation enhances critical and creative skills among graduates and fosters the ability to combine cognitive and behaviour problem-solving approaches to strengthen graduates for employability. This finding upheld that of Schroder and Kruger (2019) that asserted that social innovation has a positive and significant effect on skill acquisition and that social innovation improves the quality of education, empowers students by enhancing their skills, promotes lifelong learning opportunities, reduces educational disadvantages, develop new strategies and structures for lifelong learning. This corroborated with the findings of Ismail and Mohammed (2014); Onyeike and Onyeagbako (2014); Pandey (2016) that revealed that social innovation is a new and modern way of improving, rebuilding and transforming educational system. Similarly, the studies by Rivers, Armellini, Maxwell, Allen and Durkin (2015); Sodipo (2014), pointed out that social innovation enhances skill acquisition for employability.

This result of this study that established that social innovation dimensions have significant effect on skill acquisition among graduates supported Human capital theory which declared that new ways, new ideas and improvement in education sector are a contributory factor to the development of productive capacity of an individual and that investment on education is right investment because it is key to improving human capital, increases the productivity and earnings of individuals, boost the level of productivity for the massive economic growth and development (Akhuemonkhan et al., 2013; Robert, 1991; Sofoluwe et al., 2013). This implies that improvement in the educational system via social innovation dimensions are instrumental to the development of individuals and nations because for any graduate to be employable, he or she needs a good education and relevant skills to boost their productivity level, and to contribute to economic growth and development

Furthermore, the findings of this study displayed that educational innovation as a dimension of social innovation has a positive and significant effect on skill acquisition among graduates, this supported Aloysius et al. (2018) who asserted that educational innovation enhances school curriculum by addressing and designing essentials skills that will build up graduates' productivity at workplace, boost their career development, and make them self-reliant after graduation. The finding of the study also upheld the study by Dahunsi (2017) conducted in Nigeria which explained that social innovation dimension like educational innovation has a positive and significant interaction with skill acquisition among graduates. The studies asserted that training on soft skills enhances the school curriculum by addressing and designing essentials skills that will build up graduates' productivity at the workplace, boost their career development, and make them self-reliant after graduation. This result also aligned with the view of Sarkar et al. (2016) that explained that educational innovation helps to address the problem of skill mismatch among graduates by helping to develop necessary skills in them via curricula review and that there is need for a shift from the old traditional method of teaching to more inquiry-oriented learning to help students learn real problem-solving skills across a range of situations. However, the result of this study contracted the findings by Orji (2013) that asserted that educational innovation has no significant 
effect on skill acquisition with the argument that relevant skills for employment are probably best learned in workplaces rather than in classroom settings. Supporting the finding of this study that digital innovation as a dimension of social innovation has a positive and significant effect on skill acquisition among Nigerian graduates is the study by ÁlvarezFlores et al. (2017) and Lyons et al. (2019) that claimed that digital innovation bridges the gap between digital skills and employability and better prepare the students for skilling, reskilling and upskilling vulnerable workers. Supporting this assertion, Green (2015) maintained that the use of digital innovation like flipping classroom method provides a richer curriculum for the students which helps them keep pace with digital and technological changes that revolutionize education. On the contrary, Alghamdi (2016) found a negative association between digital innovation and skill acquisition. The study revealed that although digital innovation helps students to gain vast amounts of knowledge, yet could have a negative effect on the personal, emotional and mental life of the users.

However, this study revealed that entrepreneurship education as a dimension of social innovation has a positive but insignificant effect on skill acquisition which supported the finding of Fayomi \& Fields (2016) that reported that entrepreneurship education is nothelpful in developing of skills. However, this finding contradicted the findings of previous researchers that opined that entrepreneurship education has a significant effect on skill acquisition. For instance, Akingbade and Aberuagba (2019) reported that a positive and significant interaction exists between entrepreneurship education and skill acquisition. The study asserted that quality entrepreneurial education supports the development of business skill and support the modeling of self-reliant entrepreneurs. Similarly, the study by Yan et al. (2018) revealed that entrepreneurial training has a positive impact on the development of skills among graduates and that innovation in entrepreneurial education fosters the development of skills relevant for future career and other issues in daily life. This upheld the findings of Oresanya et al. (2014) that opined that practical entrepreneurship education prepares undergraduates for gainful employment in a professional area. The insignificant interaction between entrepreneurship education and skill acquisition as shown by the result of this study could be due to the challenges militating against the activities of entrepreneurship education in Nigerian schools. Nnaji and Bagudu (2017); Osakwe (2015); Sofoluwe et al. (2013) stated that some of the challenges facing the development of entrepreneurship education in Nigeria include the use of irrelevant entrepreneurship curriculum in schools, poor teaching methods, inadequate competent lecturers to make the course practical and goal-oriented rather than theoretical instructions, inadequate teaching materials, lack of awareness of entrepreneurship education, lack of counseling and orientation on the importance of acquiring skills, lack of systematic plans that can address the existing gap of entrepreneurship education in tertiary institutions, inadequate collaboration with experts, inadequate infrastructural/instructional facilities, harsh business climate and environment, unstable social and political climate, absence of credit policy that addresses the specific needs of enterprises and insufficient provision of funds by the government.

Furthermore, the findings of this study showed that agricultural innovation has a negative and insignificant effect on skill acquisition of graduates in Nigeria. It implied that agricultural innovation is not effective in fostering skill acquisition among students. The ineffectiveness could be linked to the challenges of agricultural innovation in Nigeria. Woldemichael, Salami, Mukasa, Simpasa and Shimeles (2017) reported that agricultural innovation fails due to challenges like poor access to infrastructure such as roads and railways network, irregular supply of energy and electricity, poor water supply, poor access to finance, poor accessibility to international and regional markets, the use of outdated and dangerous agricultural machinery, unstable environmental policies and regulations among others. According to Adejuwon (2018), some of the problems include absence of essential infrastructure such as R\&D, financial and telecoms infrastructure, lack of formalized rules such as intellectual property regulations that can incentivize innovation, network failure which refers to lack of connectedness or linkages among actors in an agricultural innovation system and lack of human capacity to utilize the innovation system. Ogunniyi, Oluseyi, Adeyemi, Kabir and Philips (2017) believed the agricultural innovation system has failed due to political instability, bureaucracy, misappropriation of funds, and poor management.

\section{Conclusion and Recommendations}

The focus of this study was to establish the effect of social innovation dimensions on skill acquisition among university graduates in Nigeria. The result revealed that social innovation has a positive and significant impact on skill acquisition among university graduates which implies that skill acquisition among students can be enhanced through social innovation. The findings further revealed that education innovation and digital innovation have a positive and significant effect on skill acquisition while entrepreneurship education has a positive but insignificant effect on skill acquisition and agricultural innovation has a negative and insignificant effect on skill acquisition among graduates in Nigeria. Hence, the educational sectors should be improved via social innovation to produce graduates that are responsible, competent and capable of contributing successfully to enterprise progress and to create employment for themselves and other job seekers. Based on the findings, the study recommended that:

- There should be curriculum reforms that will promote the use of social innovation for the development of essential skills to bridge the skill gap among Nigerian graduates.

- The educational sector, school management, lecturers, instructors should key on to the enormous benefits of adopting social innovation to enhance the teaching of the basic skills needed by students to make them employable and competitive in the labour market also competent to manage any business successfully.

- The government should develop policies that will address the reformation of curriculum that is relevant to the current modern workplace, support, finance, and encourage the development of social innovation in schools to enhance skill acquisition among graduates. 
- The government should support institutions through partnership and collaboration with social entrepreneurs and non-governmental organizations in enhancing skill acquisition, create social impact, solve social issues, provide more employment opportunities that will develop the economy through the instrument of social innovation.

\section{References}

i. Adejuwon, 0. 0. (2018). User-producer interactions: Policy implications for developing appropriate innovations for small-scale agricultural production in sub-Saharan Africa. African Journal of Science, Technology, Innovation and Development. 11(1), 1-12. DOI: 10.1080/20421338.2018.1525844.

ii. Afolabi, A. (2015). The effect of entrepreneurship on economy growth and development in Nigeria. International Journal of Development and Economic Sustainability, 3(2), 49-65.

iii. Ajufo, B. I. (2013). Challenges of youth unemployment in Nigeria: Effective career guidance as a panacea. African research review. An International Multidisciplinary Journal, 7(1), 28-35.

iv. Akhuemonkhan, I. A., Raimi, L., \& Sofoluwe, A. O. (2013). Entrepreneurship education and employment stimulation in Nigeria. Journal of Studies in Social Sciences, Infinity, 3(1), 55-79.

v. Akingbade, W. A., \& Aberuagba, O. T. (2019). Entrepreneurial education for youth business skills development in Lagos state. LASU Journal of Management Science, 5(1), 13 - 20.

vi. Akinyemi, S., Ofem, I. B., \& Ikuenomore, S. O. (2012). Graduate turnout and graduate employment in Nigeria. International Journal of Humanities and Social Science, 2(14), 257 - 265.

vii. Alghamdi, Y (2016). Negative effects of technology on children of today. International Journal of Obesity, 2(8), 1-13.

viii. Almendarez, L. (2011). Human capital theory: Implications for educational development. Conference paper. $\begin{array}{llll}\text { Retrieved } & \text { December } & 13, & 2018\end{array}$ https://www.open.uwi.edu/sites/default/files/bnccde/belize/conference/papers2010/almendarez.html

ix. $\quad$ Aloysius, O. I., Ismail, I. A., Suandi, T., \& Arshad, M. M. (2018). Enhancing university's and industry's employabilitycollaboration among Nigeria graduates in the labor market. International Journal of Academic Research in Business and Social Sciences, 8(7), $32-48$.

x. Álvarez-Flores, E. P., Núñez-Gómez, P., \& Rodríguez, C. (2017). E-skills acquisition and deficiencies at the university in the context of the digital economy. Revista Latina de Comunicación Social, 72(1), 540-559.

xi. Amadioha, S. W. (2016). Research and innovations in curriculum design and development in Nigeria: The role of the teacher in the 21st century. Journal of Teacher Perspective, ResearchGate, 11(1), 66-76.

xii. Bock, B. B. (2012). Social innovation and sustainability; How to disentangle the buzzword and its application in the field of agriculture and rural development. Studies in Agricultural Economics, 5(3), 57-63.

xiii. Ciriello, R. F., Richter, A., \& Schwabe, G. (2018). Digital innovation. Business and Information Systems Engineering, SpringerLin, 60(6), 563-569.

xiv. Dahunsi, T. N. (2017). Graduate employability and communication skills: An investigation of Nigerian graduates' proficiencies and areas of deficiencies in written English. World Journal of English Language, 7(3), 49-61.

xv. Darling-Hammond, L. (2017). Teacher education around the world: What can we learn from international practice? European Journal of Teacher Education, 40(3), 291-309.

xvi. Dhalum, N. C. (2017). Employability skills required by accounting graduates for careers in accounting. $A T B U$, Journal of Science, Technology \& Education, 5(2), 27-36. DOI 10.1108/JSTPM-04-2017-0014.

xvii. Diyoke, C. I. (2014). Entrepreneurship development in Nigeria: Issues, problems and prospects. International Journal of Technical Research and Applications, 10(1), 19-23.

xviii. Edinyang, S. D., Odey, C. O., \& Gimba, J. (2015). Academic factors and graduate employability in Nigeria. Global Journal of Human Resource Management, 3(5), 9 -17.

xix. Egbefo, D. 0., \& Abe, M. 0. (2015). Entrepreneurship education: A vital instrument for youth empowerment, industrial development and consolidation of national integration in Nigeria. An International Multi-Disciplinary Journal, 11(45), 28-48.

xx. Ekong, U. M., \& Ekong, C. U. (2016). Skills acquisition and unemployment reduction in Nigeria: A case study of National Directorate of Employment (NDE) in Akwa Ibom State. International Journal of Economics \& Management Sciences, 5(4), 1-10.

xxi. Ezeh, S. C., \& Ekemezie, C. A. (2015). Evaluation of entrepreneurial skills needed by the students of universities for self reliance and sustainable development in the south-east Nigeria. Journal of Emerging Trends in Educational Research and Policy Studies, 6(7), 236-243.

xxii. Fayomi, E. J., \& Fields, Z. (2016). Curriculum contents reform and graduate entrepreneurship training in Nigerian universities. International Journal of Educational Sciences, 14(1), 121-129.

xxiii. Fitzsimons, P. (2015). Human Capital Theory and Education. Encyclopedia of Educational Philosophy and Theory, 1-4. Doi:10.1007/978-981-287-532-7_331-1

xxiv. Food and Agricultural Organisation of the United Nations (2018). Agricultural innovation. Sowing the seeds of transformation to achieve the sustainable development goals. Retrieved January 10, 2019, from http://www.fao.org/3/CA2460EN/ca2460en.pdf Hubert, A. (2010). Empowering people, driving change: Social innovation in the European Union. Journal of Enterprising Culture, 12(1), 55 -78.

xxv. Green, T. (2015). Flipped classrooms: An agenda for innovative marketing education in the digital era. Marketing Education Review, 25(3), 179-191.

xxvi. Idoko, C. S. (2014). Skill acquisition and youth empowerment in Nigeria. Global Journal of Commerce and Management Perspective, 3(1), 51-54. 
xxvii. Irungu, K. R., Mbugua, D., \& Muia, J. (2015). Information and communication technologies (ICTS) attract youth into profitable agriculture in Kenya. East African Agricultural and Forestry Journal, 81(1), 24-33.

xxviii. Ismail, S., \& Mohammed, D. S. (2014). Employability skills in TVET curriculum in Nigeria federal universities of technology. 4th World Congress on Technical and Vocational Education and Training (WoCTVET), 5th-6th November 2014, Malaysia.

xxix. Kayode-Adedeji, T. K., \& Agwu, E. M. (2015). Application of ICT to agriculture as a panacea to unemployment in Nigeria. International Journal of Advanced Multidisciplinary Research and Review, 3(4), 26-48.

xxx. Kovacova, J. (2015). Phenomena of social innovation: Practical attempts from Slovakia. International Journal of Social Sciences, 4(4), $30-41$.

xxxi. Longe, O. (2017). Graduate unemployment in Nigeria: Causes, consequences and remediable approaches. American International Journal of Contemporary Research, 7(4), 63-73.

xxxii. Lyons, A. C, Zucchetti, A., Kass-Hanna, J., \& Cobo, C. (2019). Bridging the gap between digital skills and employability for vulnerable populations. The future of work and education for the digital age, $20(1), 1$ - 16.

xxxiii. McGuinness, C., \& Fulton, C. (2019). Digital literacy in higher education: A case study of student engagement with e-tutorials using blended learning. Journal of Information Technology Education: Innovations in Practice, 18(1), 128.

xxxiv. Mykhailyshyn, H., Kondur, O., \& Serman, L. (2018). Innovation of education and educational innovations in conditions of modern higher education institution. Journal of Vasyl Stefanyk Precarpathian, 5(1), 9-16.

xxxv. Nambisan, S., Lyytinen, K., Majchrzak, A., \& Song, M. (2017). Digital innovation management: Reinventing innovation management research in a digital world. MIS Quarterly, 41, 223-236.

xxxvi. Nnaji, F. 0. \& Bagudu, I. A. (2017). Entrepreneurship education: A strategy for youth empowerment and employment generation. Nigerian Journal of Business Education, 4(2), 55 - 66.

xxxvii. Odumosu, A. A., Binuyo, A. O., Adefulu, A. D., \& Asikhia, O. U. (2020). Social innovation and graduate entrepreneurship in Nigeria. IOSR Journal of Business and Management (IOSR - JBM), 22(2), 48 - 55.

xxxviii. Ogundari, K., \& Bolarinwa, O. D. (2018). Impact of agricultural innovation adoption: A meta-analysis. Australian Journal of Agricultural and Resource Economics, 59(1), 1-20

xxxix. Ogunniyi, A., Oluseyi, O. K., Adeyemi, O., Kabir, S. K. \& Philips, F. (2017). Scaling up agricultural innovation for inclusive livelihood and productivity outcomes in sub-Saharan Africa: The case of Nigeria. African Development Review, 29(2), 121-134.

xl. Ojo, L. B., \& Abayomi, A. A. (2014). Entrepreneurship education: A viable tool for youth empowerment in Nigeria. Academic Journal of Interdisciplinary Studies, 3(4), 11-20.

xli. Okolie, U. C., Elom, E. N., Ituma, A., Opara, P. N., Ukwa, N. J., Inyiagu, E. E., \& Ndem, J. (2014). Influence of entrepreneurship education on students attaining business development awareness and skills acquisition in Nigeria. IOSR Journal of Research \& Method in Education (IOSR-JRME), 4(3), 37-44.

xlii. Onu, V., Eskay, M., Obiyo, N., N., I. J., \& Ezeanwu, A. (2012). Innovation for transformation in Nigeria University Education: Implications for the production of critical and creative thinkers. US-China Education Review, 2(1), 229239.

xliii. Onyeike, V. C., \& Onyeagbako, S. O. (2014). Enhancing employability through university education: The role of National University Commission (NUC). Global Journal of Educational Research, 13(1), 109-115

xliv. Oresanya, T. O., Omodewu, O. S., Kolade, T. T., \& Fashedemi, A. O. (2014). Vocational education and employability: The Nigerian situation. Journal of Poverty, Investment and Development - An Open Access International Journal, 5(1), $158-160$.

xlv. Orji, N. S. (2013). Assessment of employability skills development opportunities for senior secondary school chemistry students. Journal of Educational Research and Reviews, 1(2), 16-26.

xlvi. Osakwe, R. N. (2015). Entrepreneurship education in Delta state tertiary institution as a means of achieving national growth and development. International Journal of Higher Education, 4(1), 182-186.

xlvii. Pandey, S. (2016). Improvising skill development \& employability potential through higher education, research \& innovations in India. International Journal of Innovative Research in Science, Engineering and Technology, 5(1), 680 $-688$.

xlviii. Pisante, M., Stagnari, F., \& Grant, C. A. (2012). Agricultural innovations for sustainable crop production intensification. Italian Journal of Agronomy, 7(40), 300-311.

xlix. Rivers, B. A., Armellini, A., Maxwell, R., Allen, S., \& Durkin, C. (2015). Social innovation education: Towards a framework for learning design. Higher Education, Skills and WorkBased Learning, Emerald Insight, 5(4), 383-400.

l. Robert, B. (1991) Economic growth in a cross section of countries. Quarterly Journal of Economic, 106 (2), $407-$ 414.

li. Sarkar, M., Overton, T., Thompson, C., \& Rayner, G. (2016). Graduate employability: Views of recent science graduates and employers. International Journal of Innovation in Science and Mathematics Education, 24(3), 31-48.

lii. Schroder, A., \& Kruger, D. (2019). Social innovation as a driver for new educational practices: Modernising, repairing and transforming the education system. Sustainability, 11(4), 1 - 25. Doi:10.3390/su11041070.

liii. Shivoro, R. S., Shalyefu, R. K., \& Kadhila, N. (2018). Perspectives on graduate employability attributes for management sciences graduates. South African Journal of Higher Education, 32(1), 216 - 232.

liv. Skillsan, (2012). Three types of skill classification. Retrieved April 13, 2019, from https://www.skillscan.com/sites/default/files/Three\%20Types\%20of\%20Skills\%20Classification.pdf 
lv. Sodipo, O. O. (2014). Employability of tertiary education graduates in Nigeria: Closing the skills-gap. Global Journal of Human Resource Management, 2(3), 28-36.

lvi. Woldemichael, A., Salami, A. Mukasa, A., Simpasa, A., \& Shimeles, A. (2017). Transforming Africa's agriculture through agro-industrialization. African Economic Brief, 8(7), 1 - 12.

lvii. Yan, L., Yinghong, Y., Lui, S. M., Whiteside, M., \& Tsey, K. (2018). Teaching 'soft skills' to university students in China: The feasibility of an Australian approach. Educational Studies, 1-17. Doi:10.1080/03055698.2018.1446328 